\title{
Thyroid Cancer in Clinical Practice
}


I. Ross McDougall

Thyroid Cancer in Clinical Practice

望 Springer 


\section{Ross McDougall}

Professor of Radiology and Medicine

Division of Nuclear Medicine

Stanford University Hospital and Clinics

Stanford, CA

USA

British Library Cataloguing in Publication Data

McDougall, I. Ross

Thyroid cancer in clinical practice

1. Thyroid gland-Cancer

I. Title

$616.9^{\prime} 9444$

ISBN-13: 9781846285448

Library of Congress Control Number: 2006940320

ISBN-10: 1-84628-544-5 e-ISBN-10: 1-84628-748-0

ISBN-13: 978-1-84628-544-8 e-ISBN-13: 978-1-84628-748-0

Printed on acid-free paper.

() Springer-Verlag London Limited 2007

Apart from any fair dealing for the purposes of research or private study, or criticism or review, as permitted under the Copyright, Designs and Patents Act 1988, this publication may only be reproduced, stored or transmitted, in any form or by any means, with the prior permission in writing of the publishers, or in the case of reprographic reproduction in accordance with the terms of licences issued by the Copyright Licensing Agency. Enquiries concerning reproduction outside those terms should be sent to the publishers.

The use of registered names, trademarks, etc. in this publication does not imply, even in the absence of a specific statement, that such names are exempt from the relevant laws and regulations and therefore free for general use.

Product liability: The publisher can give no guarantee for information about drug dosage and application thereof contained in this book. In every individual case the respective user must check its accuracy by consulting other pharmaceutical literature.

$9 \begin{array}{llllllll}9 & 7 & 6 & 5 & 4 & 3 & 2 & 1\end{array}$

Springer Science + Business Media

springer.com 
To the future generation of McDougalls

-Hudson, Logan, and Islay 


\section{Preface}

The number of patients diagnosed with thyroid cancer is increasing dramatically in the United States, and there are more than 30,000 new cases annually. About $5 \%$ of adults have a thyroid nodule that can be felt and between $30 \%$ and $50 \%$ have one or more nodules that can be identified by ultrasound. Thyroid Cancer in Clinical Practice covers all aspects of the diagnosis and treatment of thyroid cancer. The author has spent more than 35 years in Nuclear Medicine and Thyroidology in the clinical care of patients with thyroid nodules and or thyroid cancer. He has published 150 peer-reviewed articles and more than 100 reviews and book chapters, the majority devoted to these topics. The text includes evaluation of a patient with a thyroid nodule. The fundamentals of thyroid pathology are presented. The management of thyroid cancer in adults, children, and pregnant women is covered separately. There is discussion of whole-body scintigraphy with ${ }^{123} \mathrm{I}$, treatment by surgery and ${ }^{131} \mathrm{I}$, and the role of thyroglobulin measurements. The importance of long-term follow-up using clinical examination, scintigraphy, ultrasound, and serum thyroglobulin measurements is presented. There are separate chapters devoted to anaplastic cancer, medullary cancer, lymphoma of the thyroid, and metastases to the thyroid. The pocket-sized book provides an easily accessible source of information and advice to help practitioners manage patients and to understand when to refer for consultations. The book supplements existing large texts. Despite its pocket size, the text includes images and up-to-date procedures such as fused positron emission tomography/computed tomography images. There are more than 450 scientific citations from journals. The book should be a convenient reference for practitioners and trainees in endocrinology, nuclear medicine, oncology, surgery, including otolaryngology, radiation, and medical oncology. Medical students, nurse practitioners, and patients with a thyroid nodule or thyroid cancer should find this to be a substantial resource. 


\section{Contents}

Preface

1 Epidemiology and Etiology of Thyroid Nodules and Thyroid Cancers

2 Thyroid Anatomy and Physiology ............. 17

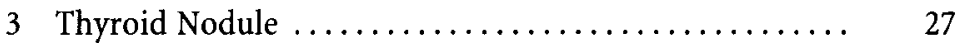

4 Thyroid Pathology $\ldots \ldots \ldots \ldots \ldots \ldots \ldots \ldots \ldots . . \ldots \ldots$

5 Differentiated Thyroid Cancer $\ldots \ldots \ldots \ldots \ldots \ldots \ldots \ldots, 53$

6 Differentiated Thyroid Cancer: Rare Clinical Situations $\ldots \ldots \ldots \ldots \ldots \ldots \ldots \ldots \ldots \ldots \ldots . \ldots \ldots, 92$

7 Differentiated Thyroid Cancer in Children $\ldots . . . \ldots . \quad 100$

8 Thyroid Cancer and Pregnancy $\ldots \ldots \ldots \ldots \ldots \ldots \ldots, 115$

9 Anaplastic Carcinoma of the Thyroid ............ 124

10 Medullary Cancer $\ldots \ldots \ldots \ldots \ldots \ldots \ldots \ldots \ldots \ldots . \quad 132$

11 Primary Lymphoma of the Thyroid ............. 145

12 Metastases to the Thyroid $\ldots \ldots \ldots \ldots \ldots \ldots \ldots \ldots \ldots . \quad 149$

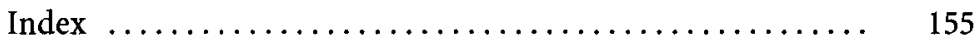

